\title{
Reviews
}

\section{Carmen África Vidal Claramonte. Traducción, manipulación, desconstrucción. Colección Biblioteca Filológica de Salamanca. Salamanca: Ediciones Colegio de España, 1995.}

It is some considerable time since Translation, as an independent academic discipline, took its place in Spanish universities. Since then several journals and professional publications have appeared, serving to disseminate theoretical reflections on traductology and work on literary, technical, and legal translation, among others. The number of these publications has increased over the last few years, and the accumulated experience has also given rise to an increase in quality. It is within this parameter of quality that a place of honour is occupied by M. Carmen África Vidal Claramonte's recent book Traducción, manipulación, descontrucción. Because of its originality and the treatment given to its contents, this book has become an essential text for students of translation and traductology.

Dr. Vidal Claramonte combines two highly valuable qualities which enable her to theorize with agility, imagination and mastery on translation and traductology: her experience as a translator and her thorough linguistic training. Her translation experience includes the translation into Spanish of six books and more than a hundred articles, for which she has been awarded national translation prizes; as a specialist in English studies, during the time when she was university lecturer in Alicante, she acquired the skills required to examine and write published works on the more important literary and cultural phenomena of the twentieth century, so that today she is one of the best-known specialists on the cultural phenomenon known as Postmodernism. Equipped with these theoretical and practical instruments, Dr. Vidal Claramonte offers us, in her clear, transparent prose style, three studies titled "Sobre el estado de la cuestión" ("On the State of the Question"), "La traducción como manipulación" ("Translation as Manipulation"), and "Desconstruir la traducción" (“Deconstructing Translation").

The first of these studies is an introductory review of present-day translation problems. Entitled "Sobre el estado de la cuestión," it consists of six sections which deal with six vital questions in the speciality: translation studies, the qualities required in a translator, the translator's intention, the problem of equivalence, the existence of an Ur-Sprache, and the types of translation. Those who wish to update their knowledge of the basic questions of translation will find in Dr. Vidal's work a clear, up-to-the-minute overview of these questions, based on epistemological concepts and generous references, in a 44-page chapter packed with information.

The second chapter is titled "La traducción como manipulación," and is a critical analysis of all that is represented by the so-called Manipulation School of Central European origin both linguistically and culturally. As Vidal Claramonte affirms, "the 
'Manipulation School' presents us with a new paradigm which prefers to put its emphasis not on interlinguistic relations but rather on intertextual ones; likewise, instead of centring its attention on potential translation or translatability, prefers to analyse translations which have already been done." Dr. Vidal brilliantly examines the philosophical foundations of this school of traductological thought and analyses in detail several of its basic concepts, among which is that of polysystem.

The third chapter, entitled "Desconstruir la traducción," is a work of applied theory. Here the author is on home ground, manipulating with ease and familiarity her own reflections on post-structuralism, Jacques Derrida's deconstruction and their application to translation.

To summarize all the foregoing, we can definitely state that whether one agrees or disagrees with the postulates of the questions examined, in particular those of the Manipulation School, or with the contribution made by post-structuralism and deconstruction to traductology, it is eminently true that the specialised reader will not remain indifferent to the imaginative analysis offered with full academic rigour by Dr. Vidal. All her personal reflection on the science and the art of translation is contained in the three chapters entitled "Sobre el estado de la cuestión," "La traducción como manipulación," and "Desconstruir la traducción," which are accompanied by abundant footnotes whose erudition and accuracy provide a solid intellectual base for what she affirms elsewhere, as well as helping the reader to discover new pathways for research into the theory of translation. The book ends with a wide-ranging yet select, up-to-date bibliography of works on translationand in particular on the questions analysed. This bibliography is highly valuable as a basic research instrument for advanced students of translation.

At the same time as we offer our gratitude to Dr. Vidal Claramonte for this new contribution to the world of the intellect, we should also like to make it clear that in our opinion Translation, manipulation, deconstruchon is a valuable conceptual work which should occupy its rightful place on the theory of translation bookshelf, alongside the great theoreticians of translation such as Nida, Vázquez Ayora, Bassnett, Lefevre, Santoyo, Rabadán, Peña, Hurtado and others; the author has courageously approached translation in a serious, confident, academically rigorous manner and from an interdisciplinary standpoint.

Enrique Alcaraz Varó

Diccionario de uso inglés-español/Spanish-English. Directed by Aquilino Sánchez. Madrid: SGEL, 1993, 450 pp. • Diccionario de uso pocket inglés-español/SpanishEnglish. Directed by Aquilino Sánchez. Madrid: SGEL, 1993, 274 pages.

Very often, and perhaps as a result of the false cliché that would make us believe that any product coming from abroad must be better, those of us who have made English a way of life let only a limited series of publishers control the field of English teaching and translation. This has led us, on the one hand, to believe that any textbook published in 